\title{
Natural Resources, Institutional Quality and Financial Development in GCC Member Countries: Visiting 'Resource Curse Hypothesis' by DCCE Estimation
}

\author{
Muhammad Faheem ${ }^{a}$, Imran Sharif Chaudhry ${ }^{b}$, Sadam Hussain ${ }^{c}$ \\ ${ }^{a}$ Assistant Professor, School of Economics Bahauddin Zakariya University, Multan, Pakistan \\ Email: faheem@bzu.edu.pk \\ ${ }^{\mathrm{b}}$ Professor, School of Economics Bahauddin Zakariya University, Multan, Pakistan \\ Email: imran@bzu.edu.pk \\ ${ }^{c}$ PhD Scholar, Dongbei University of Finance and Economics, China \\ Email: sadam_2iqbal@yahoo.com
}

\begin{tabular}{|c|c|}
\hline $\mathbf{A R}$ & \multirow{11}{*}{$\begin{array}{l}\text { ABSTRACT } \\
\text { The main purpose of the study is to check whether natural resource rent } \\
\text { affects the financial development or supporting the resource curse } \\
\text { hypothesis by employing a recently developed estimation technique by } \\
\text { Chudik and Pesaran (2015) from } 1985 \text { to } 2017 \text { in GCC member countries. } \\
\text { The novelty of this methodology is to consider structural breaks and the } \\
\text { heterogeneity issues that are common in panel data. The results of DCCE } \\
\text { estimates are in support of the resource hypothesis that natural resource } \\
\text { rent hurt financial development. Additionally, this study takes } \\
\text { moderation of institutional quality to check the threshold point or } \\
\text { turning point where the natural resource rent effect becomes positive. } \\
\text { Our results of interaction term postulate that a higher level of } \\
\text { institutional quality mitigates the adverse effect of natural resource rent } \\
\text { on financial development. The study results recommend the policy of } \\
\text { natural resource rent in the presence of high institutional quality should } \\
\text { continue because it improves the financial development in GCC member } \\
\text { countries. }\end{array}$} \\
\hline & \\
\hline & \\
\hline$A$ & \\
\hline Key & \\
\hline & \\
\hline Qua & \\
\hline $\mathrm{Cou}$ & \\
\hline JEL & \\
\hline A19, & \\
\hline & \\
\hline
\end{tabular}

(C) 2021 The authors. Published by SPCRD Global Publishing. This is an open access article under the Creative Commons Attribution-

NonCommercial 4.0

Corresponding author's email address: imran@bzu.edu.pk

\section{Introduction}

The financial development role is central for greater prosperity achievement, and an efficient financial system is needed to encourage natural resources efficient for the growth of any economy (Pradhan et al., 2016; Nawaz et al., 2019). Financial development also improves financial intermediary services' quality and quantity (Muhammad et al. 2016). Stabilization and commercial banking assets, net interest margins, and creation of creating credit circulation are the source of financial indicators stability (Dwumfour and Ntow-Gyamfi, 2018) that contribute to economic growth but in low strength in resource abundance countries (Sachs and Warner, 2001; Gelb, 2010). The development of any economy's natural resources plays a crucial role for the countries as it is an asset of a country (Guan et 


\section{Review of Economics and Development Studies, Vol. 7 (2) 2021, 131-145}

al., 2020), and that is in discussion since Smith (1776) and Ricardo (1917). It helps to generate economic activities and recorrect trade balance through institutional performance, good governance indicators, and financial development (Asif et al., 2020). On the contrary, under certain conditions, resource abundance creates an exigent environment for financial sector development. Nevertheless, in recent times several economies have high natural resources but lagging in economic growth from countries that have fewer resources (Badeeb et al., 2017).

In theory, the resource curse concept assumes the cause of the economic collapse of assets plentiful nations, and experimentally, it was shown that in the mainstream of surveys (Sachs and Warner, 2001). The investigation described numerous reasons that trigger the resource curse hypothesis, for example, dishonesty, rental pursuing actions, fallback industrial sector financing, and inferior organizational quality and goods price shocks in assets-rich nations (Mlachila and Quedraogo, 2019). Economic growth is supposed to be a foundation for moving capital curse into capital benediction in the existence of higher organizational superiority, high-level trade, and great value of human capital (Rajan and Zinglaes, 2013).

Previous literature has shown that institutional quality important determinant of financial development (Law et al., 2014; Kirch and Terra, 2012; Law and Habibullah, 2006; Tamazian and Rao, 2010). Many researchers reported a positive relation (Khan et al., 2020; Bhattacharyya and Hodle, 2014). In contrast, others found a negative relation (Hunjra et al., 2020). The literature revealed a damaging linkage of sources with economic advancement (Cardon and Neary, 1982; Zoega and Gylfascon, 2001; Guan et al., 2020; Sun et al., 2020). On the other side, there is a work in the paradox of the research and revealed a positive relationship (Auty, 2001; Gokmenoglu and Rustamov, 2019; Nawaz et al., 2019). So, our investigation provides policy direction for the accomplishment of financial expansion along with efficient natural assets use in the GCC countries.

This remaining is organized in the following sections: part 2 reviews previous studies. Part 3 detail the methodology. Part 4 expresses the results and the final section draw concluding remarks and suggestions.

\section{Literature Review}

A glut of empirical literature investigated the association of natural resource with macroeconomic indicators, like natural resource and economic growth (Fum and Hodler, 2010; Alexeev and Chernyavskiy, 2015; Erum and Hussain, 2019; Atil et al.,2020); inflation (Ouoba, 2016; Kim and Lin, 2017; Henri, 2019; Freeman et al., 2020; Chaudhry et al., 2021) unemployment ( Sjöberg et al., 2010; Kayode et al., 2014; Bagchi and Paul, 2018; Mukoka, 2020) trade balance (Vallejo, 2010; Gill et al., 2014; Harding and Venables, 2016; Tran et al., 2020); poverty (Barbier, 2010; Timilsina and Zilberman, 2016; Marchand and Weber, 2018); environment (Simon, 2010; Panayotou, 2016; Ding and Peng, 2018; Badeeb et al., 2020).

However, limited studies revealed the link of natural resources with the financial sector (Shahbaz et al., 2013; Bhattacharyya and Hodler, 2014; Hattendorff, 2014; Suliman and Elian, 2014). The overwhelming part of the literature demonstrates a positive association of natural resources with financial development like, (Nwani, 2016; Zaidi et al., 2019; Ibrahim, 2019; Faisal et al., 2019; Y1ldırım et al., 2020) and other negatives (Khan et al., 2020).

Many studies reported a positive association link of natural resources with the financial development of countries (Nwani, 2016; Ibrahim, 2019; Zaidi et al., 2019; Khan et al., 2020). Khan et al. 


\section{Review of Economics and Development Studies, Vol. 7 (2) 2021, 131-145}

(2020) indicate a linkage between financial development and natural resources by employing maki cointegration and multiple structural break approach evidence from China positively. Recently, Yildırım et al. (2020) reported the positive influence of natural resources on financial development evidence from 16 countries. In contrast, Asif et al. (2020) used the ARDL approach and empirical results reported that natural resources harm financial development in the long run in Pakistan. Evidence from China, Guan et al. (2020) reported the negative effect of natural resources on financial development overused time-series data from 1971-2017 by employing the ARDL approach. Similarly, Bhattacharyya and Hodler (2014) argued that if the political-institutional quality is poor, so the result reported with statistical evidence that found a negative association. In China, Yuxiang and Chen (2011) tested how natural resources affected financial development overtime the period 1996 to 2006 by employing the GMM model. The result indicates that natural resources hurt financial development.

In eight Asian countries, Law et al. (2014) tested the relation between institutional quality and financial development over time from 1984 to 2006 by employing an econometric heterogeneous panel cointegration test. The empirical result reported a positive influence of institutional quality on financial development. In ninety developed and developing countries, Huang (2010) revealed the association of financial development and political intuition by employing the GMM model overusing panel data from 1960 to 1999. The result statistically indicates a positive association. In contrast, Girma and Shortland (2008) investigated the influence of political intuition on financial development by employing the GMM model. The statistical result indicates that political institution has positively affected to financial development.

Law et al. (2015) tested the influence of real GDP with other variables like institutional quality and globalization on financial development over the time from 1984 to 2008 in East Asian countries. The empirical analysis result indicates that real GDP affected positively. Atil et al. (2020) explores the association of real GDP, oil price, natural resource, and globalization with financial development in Pakistan over 1972-2017 and found real GDP associated positively with financial development. Similarly, Satti et al. (2014) found the granger causality relationship.

In the case of GCC panel countries, Grassa and Gazdar (2014) by employing OLS, and GLS approaches, and result indicates the negative and significant impact of financial development on economic growth. In contrast, Bist (2018) analyzed the association of financial development on economic growth in the long run by employing the OLS approach over using panel data of 20 years.

From the previous literature, it can be wrap up those ambiguous findings exists in literature and there is a need to address this issue in the context of oil-exporting countries like GCC member countries that are highly resource-abundant.

\section{Data and Methodology}

For the testing of the resource curse hypothesis, our study uses financial development (proxied by broad money to GDP) as a dependent variable. The regressors are natural resource rent, gross domestic product (GDP), institutional quality (INSQ), and the interaction term of institutional quality and natural resource (NRR*INSQ) and all variables are taken in logarithmic form, and description reported in table A1 (see appendix). The study covers the period 1985-2017 for GCC member countries.

Different methodologies have been used in previous studies to prove the resource curse hypothesis. Some are on time series data like ARDL, NARDL, VAR and others are on a panel like GMM, fixed and random effect, panel ARDL. These methods are traditional methods and unable to cover 
severe issues related to heterogeneity, cross-sectional dependence, and structural breaks. The study uses the recently developed methodology that covers this issue and provides reliable estimates.

\subsection{DCCE Estimation Methodology}

A recently developed dynamic common correlated effects (DCCE) method by Chudik and Pesaran (2015) solves the previous studies' issues that make them inefficient and unreliable for estimation. This method solves the issue of cross-sectional dependence (CSD) which was not entertained in previous studies by taking cross-sectional averages and lagged CS averages of the dependent variable with regressors. This method also entertains the heterogeneity issue in the parameters with the assistance of the mean group method and suitable, even small sample size. The beauty of this methodology is that it gives reliable estimates to even have unbalanced data and structural breaks (Kapetanios et al. 2011; Ditzen, 2016; Ditzen, 2019).

The study empirically tested the resource curse hypothesis in the specification DCCE estimation by taking financial development as the dependent variable and natural resource rent, real GDP, institutional quality, an interaction term of institutional quality, and natural resource rent as independent variables.

The concerned model is composed in the following equation:

$$
Y_{i t}=\alpha_{i} Y_{i t-1}+\delta_{i} X_{i t}+\sum_{p=0}^{p_{T}} \gamma_{x i p} \bar{X}_{t-p}+\sum_{p=0}^{p_{T}} \gamma_{y i p} \bar{X}_{t-p}+\mu_{i t}
$$

In the above equation Yit, Yit-1 and Xit represent the dependent variable, lag of dependent variable, and independent variable, respectively. The cross-sectional time and dimension are denoted by $\mathrm{i}$ and t. And $\mathrm{P}_{\mathrm{T}}$ and $\mu_{\mathrm{it}}$ denotes the lag of cross-sectional averages and the error term. $\gamma_{x i p}$ and $\gamma_{y i p}$ denotes the unobserved factors.

For testing the resource curse hypothesis, we extend this in our variable formulation:

$$
L F D_{i t}=\alpha_{i} L F D_{i t-1}+\beta_{i} X_{i t}+\sum_{p=0}^{p T} \gamma_{x i p} \overline{X_{t-p}}+\sum_{p=0}^{p T} \gamma_{y i p} \overline{X_{t-p}}+\mu_{i t}
$$

In the above equation, LFD is the log of financial development that is used as the dependent variable, and other LNRR, LGDP, LINSQ, and (LNRR*LINSQ) are explanatory variables reported by $\mathrm{X}_{\mathrm{it}}$. $\mu_{i t}$ is the error term.

\subsection{Test of Cross-sectional Dependence (CSD)}

It can happen $\mathrm{CD}$ in the panel estimation because of interaction among countries, space effects, and unobserved factors, and estimation will provide unreliable results if these issues do not address properly (Chudik and Pesaran, 2013; Dong et al., 2018b). the widely used method to tackle this CD issue is the Lagrange multiplier (LM) test grounded in Breush and Pagan (1980) and expressed as follows:

$$
y_{i t}=\alpha_{i}+\beta_{i} x_{i t}+\mu_{i t}
$$

$\beta_{\mathrm{i}}$ and $\alpha_{\mathrm{i}}$ denotes countries individual slope coefficients and intercept. 
Breush and Pagan (1980) LM test standard form is the following:

$$
L M_{B P}=T \sum_{i=1}^{N-1} \sum_{j=i+1}^{N} \rho_{i j}^{2}
$$

Notwithstanding, there are some shortcomings in this test like it is suitable only for the large period and the small number of countries (Pesaran, 2004). Therefore, the scaled version is given by Pesaran (2004) which tackles the previous test issues.

$$
\text { Scaled LM Test }=\sqrt{\left(\frac{1}{N(N-1)}\right)}\left[\sum_{i=1}^{N-1} \sum_{j=i+1}^{N}\left(T \hat{\rho}_{i j}^{2}-1\right)\right]
$$

For the small sample and large N, Pesaran (2004) introduced the cross-sectional dependence (CD) test which is also suitable.

$$
\mathrm{CD}=\sqrt{\left(\frac{2 T}{N(N-1)}\right)}\left[\sum_{i=1}^{N-1} \sum_{j=i+1}^{N} \hat{\rho}_{i j}\right]
$$

The latest modified version of the LM test is given by Baltagi et al. (2012) for accurate mean and variance of the LM statistics:

\subsection{Unit Root Tests (First Generation and Second Generation)}

There are frequently adopted traditional first-generation unit root tests in the literature like LLC, IPS, ADF, and PP that guides variables' stationarity. But the issue is that in the case of CD, these test results are not more reliable (Pesaran, 2007). In contrast, the second-generation unit root test like CIPS introduced by Pesaran (2007) tackle these issue that first-generation unit root ignored.

\subsection{Cointegration Test (Pedroni and Westerlund)}

In the case of CSD, the results not more reliable by traditional unit root tests like Pedroni (1999). Consequently, we apply a recently developed cointegration technique developed by Westerlund (2007) that provides reliable results and cope with the issues. The specialty of this test is it considers the cointegration in panel series whether ECM present for individual or the whole panel (Persyn and Westerlund, 2008).

\section{Results and Discussion}

The summary of features of data expresses in the form of descriptive statistics and correlation shows the association, results are reported in the following table 1 of LFD, LNRR, LGDP, LINSQ, and (LNRR*LINSQ), respectively. 
Review of Economics and Development Studies, Vol. 7 (2) 2021, 131-145

Table 1: Descriptive statistics and Correlation

\begin{tabular}{|l|c|c|c|c|c|}
\hline & LFD & LNRR & LGDP & LINSQ & (LNRR* LINSQ) \\
\hline Mean & 3.9619 & 3.4665 & 25.2838 & 1.8387 & 6.3944 \\
\hline Median & 3.9529 & 3.5063 & 25.286 & 1.9284 & 6.5066 \\
\hline Maximum & 5.2587 & 4.1278 & 27.2233 & 2.1691 & 8.6051 \\
\hline Minimum & 3.2614 & 2.1613 & 23.4531 & $2.00 E-06$ & $4.32 E-06$ \\
\hline Std. Dev. & 0.3715 & 0.3599 & 1.0452 & 0.3007 & 1.2638 \\
\hline Skewness & 0.2693 & -0.7789 & 0.1026 & -2.1118 & -1.0582 \\
\hline Kurtosis & 2.8053 & 3.7047 & 1.8582 & 10.7401 & 5.8312 \\
\hline Jarque-Bera & 2.2550 & 20.0971 & 9.2519 & 534.5270 & 85.9024 \\
\hline Probability & 0.3238 & 0.0000 & 0.0098 & 0.0000 & 0.0000 \\
\hline Sum & 653.7071 & 571.9790 & 4171.821 & 303.3864 & 1055.083 \\
\hline Sum Sq. Dev. & 22.6310 & 21.2537 & 179.1699 & 14.8284 & 261.9439 \\
\hline Observations & 165 & 165 & 165 & 165 & 165 \\
\hline LFD & 1 & $-0.1189^{* *}$ & 0.1131 & -0.0814 & -0.1002 \\
\hline LNRR & & 1 & $-0.1775^{* *}$ & $0.19055^{* *}$ & $0.6529^{* * *}$ \\
\hline LGDP & & & 1 & $0.3085^{* * *}$ & $0.1434^{*}$ \\
\hline LINSQ & & & & 1 & $0.8544^{* * *}$ \\
\hline (LNRR*LINSQ) & & & & & 1 \\
\hline
\end{tabular}

To test the cross-sectional dependence is very crucial for choosing the econometric method. Different types of tests are applied like biased-corrected scaled LM test, CD test, and scaled LM test which is given by Baltagi et al. (2012), (Pesaran et al. 2004), and Pesaran (2004) to check the CSD and provides us guidance about methodology. The results of these tests report in the following table 2.

Table 2 : Panel Unit Root Tests for Cross-Sectional Dependence

\begin{tabular}{|c|c|c|c|}
\hline & Pesaran CD & Pesaran scaled LM & Breusch-Pagan LM \\
\hline LFD & $8.68 * * *$ & $24.14^{* * *}$ & $122.99 * * *$ \\
\hline LNRR & $12.37^{* * *}$ & $34.01^{* * *}$ & $167.09^{* * *}$ \\
\hline LGDP & $17.14^{* * *}$ & $62.44^{* * *}$ & $294.24^{* * *}$ \\
\hline LINSQ & $14 \cdot 31 * * *$ & $44 \cdot 55^{* * *}$ & $214.22^{* * *}$ \\
\hline (LNRR*LINSQ) & $14.71^{* * *}$ & $46.28^{* * *}$ & $221.96^{* * *}$ \\
\hline
\end{tabular}

*** show to the levels of significance at 1 percent.

Unit root tests are two types namely first and second generations unit root tests and most studies only rely on first-generation unit root tests like Levin et al. (2002), Im et al. (2003), and some other traditional unit root tests. Some issues are not covered by these unit root tests like these tests ignore the CSD, which is the most major problem in panel data. To tackle this issue and for reliable results, we use the second-generation unit root test (CIPS-Test), which is introduced by Pesaran (2007) and is useful for guidance of econometric methodology. The following table 3 of unit root test results express that variables are mixed order of integration. 
Review of Economics and Development Studies, Vol. 7 (2) 2021, 131-145

Table 3: Unit Root (First \& Second Generation) Tests Results

\begin{tabular}{|c|c|c|c|c|}
\hline \multicolumn{5}{|c|}{ Unit Root Tests (LLC \& IPS) } \\
\hline & \multicolumn{2}{|c|}{ Levin, Lin, and Chu } & \multicolumn{2}{|c|}{ Im, Pesaran, and Shin W-stat } \\
\hline & Level & First Difference & Level & First Difference \\
\hline LFD & 2.57 & $-5.76 * * *$ & 2.04 & $-7.61 * * *$ \\
\hline LNRR & $-2.36 * * *$ & $-2.96^{* * *}$ & $-3.03^{* * *}$ & $-9 \cdot 44^{* * *}$ \\
\hline LGDP & 2.08 & $-3.24^{* * *}$ & 4.39 & $-4.59 * * *$ \\
\hline LINSQ & $-2.82^{* * *}$ & $-7 \cdot 33^{* * *}$ & $-1.56^{*}$ & $-6.85^{* * *}$ \\
\hline$(\mathrm{LNRR} * \mathrm{LINSQ})$ & $-1.87^{* *}$ & $-3.95^{* * *}$ & $-1.34^{*}$ & $-7.19 * * *$ \\
\hline \multicolumn{5}{|c|}{ Unit Root Test (CIPS) } \\
\hline & \multicolumn{2}{|c|}{ Level } & \multicolumn{2}{|c|}{ First Difference } \\
\hline LFD & \multicolumn{2}{|c|}{-1.52} & \multicolumn{2}{|c|}{$-5 \cdot 39 * * *$} \\
\hline LNRR & \multicolumn{2}{|c|}{$-3.13 * * *$} & \multicolumn{2}{|c|}{$-5 \cdot 46 * * *$} \\
\hline LGDP & \multicolumn{2}{|c|}{-2.23} & \multicolumn{2}{|c|}{$-4 \cdot 56 * * *$} \\
\hline LINSQ & \multicolumn{2}{|c|}{-1.99} & \multicolumn{2}{|c|}{$-4 \cdot 19 * * *$} \\
\hline$(\mathrm{LNRR} * \mathrm{LINSQ})$ & \multicolumn{2}{|c|}{$-2.62 * *$} & \multicolumn{2}{|c|}{$-4.98 * * *$} \\
\hline
\end{tabular}

Note: ${ }^{* *}, * *$ and $*$ show the levels of significance at 1 percent, 5 percent, and 10 percent, respectively.

The next step is to check the cointegration among the variables. For this, we applied two types of unit root tests for reliable results. First, we applied the traditional cointegration test that is introduced by Pedroni (1999), and table 4 expresses the results. The outcome of the traditional cointegration test shows there is no cointegration.

The results of the traditional cointegration test are not sufficient and reliable because it ignores the various issues like CSD, structural breaks. While the second-generation cointegration test that was introduced by Westerlund (2007) is suitable because it copes up these issues regarding structural breaks, CSD, serial correlation, and heteroskedasticity.

Table 4: Pedroni Residual (Traditional) Cointegration Test

\begin{tabular}{|l|c|c|c|c|}
\hline & t-Stat & Probability & W. Stat & Probability \\
\hline v-Stat & 0.48 & 0.31 & 0.32 & 0.37 \\
\hline rho-Stat & -0.53 & 0.29 & -0.16 & 0.43 \\
\hline PP-Stat & $-1.85^{* *}$ & 0.03 & -1.32 & 0.09 \\
\hline ADF-Stat & $-1.34^{*}$ & 0.08 & -0.92 & 0.17 \\
\hline & Stat & Probability & & \\
\hline Group rho-Stat & 0.23 & 0.59 & & \\
\hline Group PP-Stat & $-1.63^{* *}$ & 0.04 & & \\
\hline Group ADF-Stat & -1.16 & 0.12 & & \\
\hline
\end{tabular}

Note: **and * refer to $5 \%$ and $10 \%$ levels of significance, respectively.

The following table 5 reports the results of Westerlund (2007) cointegration test that show the existence of cointegration in the long run. 
Review of Economics and Development Studies, Vol. 7 (2) 2021, 131-145

Table 5: Panel Cointegration Test (Westerlund ECM)

\begin{tabular}{|c|c|c|}
\hline $\mathrm{H}_{\mathrm{o}}$ : no cointegration & Value & Probability \\
\hline $\mathrm{Gt}$ & $-3.63^{* *}$ & 0.02 \\
\hline $\mathrm{Ga}$ & $-11.01^{* *}$ & 0.01 \\
\hline $\mathrm{Pt}$ & $-7.96^{* * *}$ & 0.00 \\
\hline $\mathrm{Pa}$ & $-13.36^{* *}$ & 0.03 \\
\hline
\end{tabular}

Note: ${ }^{* *}$ and ${ }^{* *}$ refer to $1 \%$ and $5 \%$ significance level, respectively.

The findings of the DCCE model are reported in table 6. The results show our main independent variable NRR is associated with financial development negatively, which means a one percent increase in LNRR will decrease financial development by $0.28 \%$. These results support the resource curse hypothesis in GCC member economies. Other control variables affect significantly financial development. The variable LFDI shows a positive association with the ecological footprint. However, the result of our interaction term is positively significant that explains this resource curse effect minimizes and converts to a positive effect in the presence of strong institutional quality.

Table 6: Results Dynamic Common Correlated Effects (DCCE) estimation

\begin{tabular}{|l|c|c|}
\hline \multicolumn{1}{|c|}{ Regressors } & Coefficient & p-value \\
\hline LFD (-1) & $-0.79^{* *}$ & $(0.06)$ \\
\hline LNRR & $-0.28^{* *}$ & $(0.03)$ \\
\hline LGDP & $0.37^{*}$ & $(0.02)$ \\
\hline LINSQ & $0.88^{* *}$ & $(0.00)$ \\
\hline (LNRR*LINSQ) & $0.23^{* * *}$ & $(0.90)$ \\
\hline Constant & 0.44 & \\
\hline
\end{tabular}

Note: ${ }^{* *},{ }^{* *}$ and $*$ shows $1 \%, 5 \%$ and $10 \%$ significance level, respectively

Furthermore, the study finds the marginal effect at various institutional quality levels like minimum, mean and maximum level, and following table 7 and the graph presents the results.

Table 7: Marginal Effect

\begin{tabular}{|l|l|l|l|l|}
\hline & & Minimum & Average & Maximum \\
\hline $\begin{array}{l}\text { GCC member } \\
\text { Countries }\end{array}$ & $\begin{array}{l}\text { Institutional } \\
\text { Quality }\end{array}$ & $2.00 E-06$ & 1.8387 & 2.1691 \\
\cline { 2 - 5 } & Marginal Effect & -0.208 & 0.2149 & 0.2908 \\
\hline
\end{tabular}

$\delta L F D_{i t} / \delta L N R R_{i t}=-0.208+0.23 \operatorname{LINSQ}_{t}$

The marginal effect of natural resource rent on financial development is calculated at minimum, the mean and maximum level of institutional quality is $-0.208,0.2149$, and 0.2908 , respectively. 


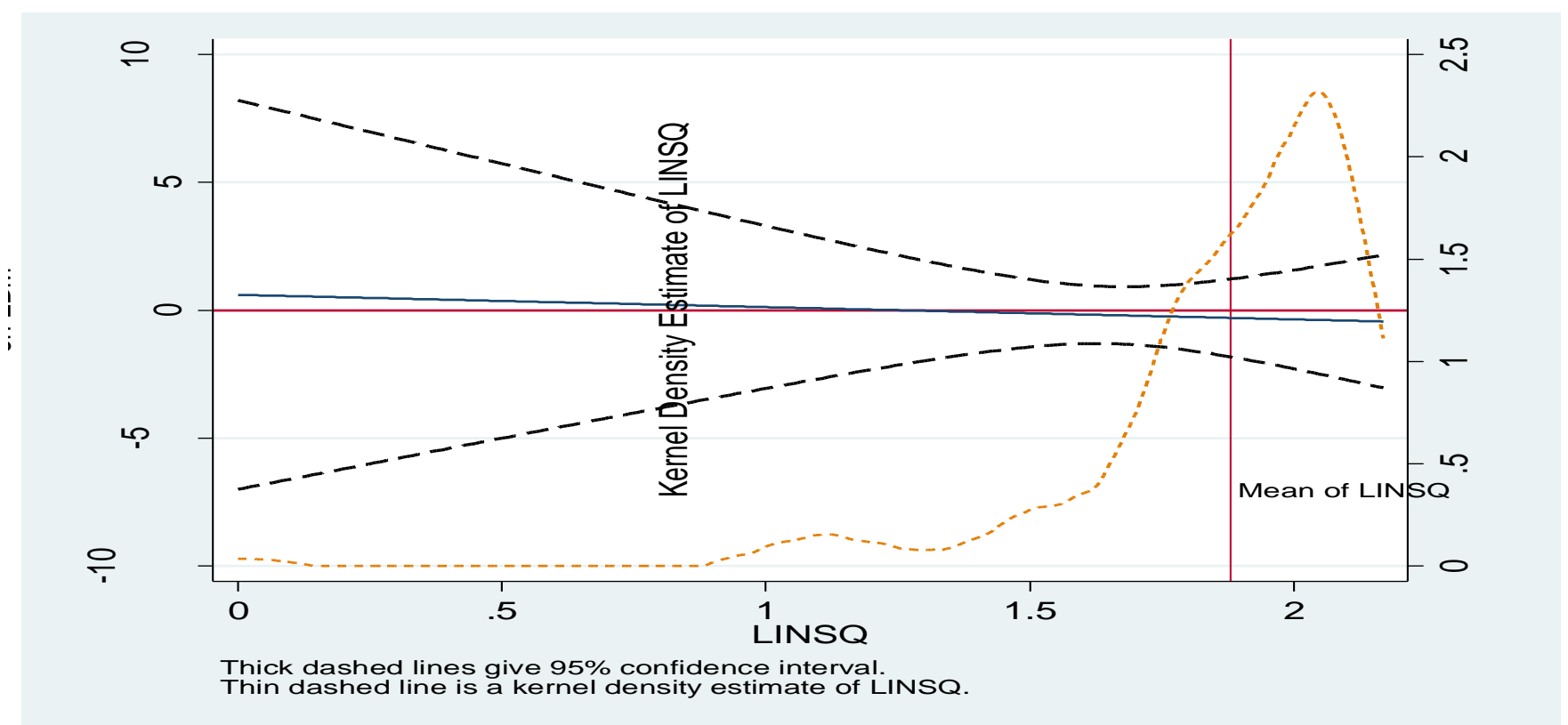

Figure 1: Marginal Effect Graph

The study further checks the robustness by using new proxy financial development, and the results are given in Table 8. The findings are consistent with the previous results reported in Table 6. Natural resource abundance hurts financial development while real GDP, institutional quality, and interaction term increase the financial development for GCC member countries.

Table 8: Robustness Check using Financial Development Index as Measure for Financial Development

\begin{tabular}{|l|c|c|}
\hline \multicolumn{1}{|c|}{ Regressors } & Coefficient & probability-value \\
\hline LFD (-1) & $-0.56^{* * *}$ & $(0.00)$ \\
\hline LNRR & $-0.57^{* * *}$ & $(0.00)$ \\
\hline LGDP & $0.15^{* *}$ & $(0.00)$ \\
\hline LINSQ & $0.45^{* * *}$ & $(0.02)$ \\
\hline (LNRR*LINSQ) & $0.17^{* *}$ & $(0.81)$ \\
\hline Constant & 0.77 & \\
\hline
\end{tabular}

Our results are in line with the empirical studies of Asif et al. (2020) that sow the adverse association of resources with financial development. The control variables real GDP, and institutional quality affect positively significant. The interaction term of natural resource rent and institutional quality is positive that postulates, resource curse hypothesis mitigated by a high level of institutional quality.

\section{Conclusion and Recommendations}

The explores the relation of natural resource rent with financial development in visiting the resource curse hypothesis in GCC member countries over 1985-2017. We employ the novel method 


\section{Review of Economics and Development Studies, Vol. 7 (2) 2021, 131-145}

DCCE approach developed by Chudik and Pesaran (2015) that have an advantage over the traditional method to cope with the cross-sectional dependence and structural breaks problem in the panel data. The results of DCCE estimates are in support of the resource hypothesis that natural resource rent harms financial development. Additionally, we take moderation of institutional quality to check the threshold point or turning point where the natural resource rent effect becomes positive. Our results of interaction term postulate that a higher level of institutional quality mitigates the adverse effect of natural resource rent on financial development. The study results recommend the policy of natural resource rent in the presence of high institutional quality should continue because it improves the financial development in GCC member countries.

\section{References}

Albuquerque, U. P., Soldati, G. T., Ramos, M. A., de Melo, J. G., de Medeiros, P. M., Nascimento, A. L. B., \& Júnior, W. S. F. (2015). The influence of the environment on natural resource use: evidence of apparency. In Evolutionary ethnobiology (pp. 131-147). Springer, Cham.

Alexeev, M., \&Chernyavskiy, A. (2015). Taxation of natural resources and economic growth in Russia's regions. Economic Systems, 39(2), 317-338.

Asif, M., Khan, K. B., Anser, M. K., Nassani, A. A., Abro, M. M. Q., \& Zaman, K. (2020). Dynamic interaction between financial development and natural resources: Evaluating the 'Resource curse' hypothesis. Resources Policy, 65, 101566.

Atil, A., Nawaz, K., Lahiani, A., \&Roubaud, D. (2020). Are natural resources a blessing or a curse for financial development in Pakistan? The importance of oil prices, economic growth and economic globalization. Resources Policy, 67, 101683.

Auty, R. M. (2001). The political economy of resource-driven growth. European economic review, 45(4-6), 839-846.

Badeeb, R. A., Lean, H. H., \& Clark, J. (2017). The evolution of the natural resource curse thesis: A critical literature survey. Resources Policy, 51, 123-134.

Badeeb, R. A., Lean, H. H., \& Shahbaz, M. (2020). Are too many natural resources to blame for the shape of the Environmental Kuznets Curve in resource-based economies? Resources Policy, 68, 101694.

Bagchi, A., \& Paul, J. A. (2018). Youth unemployment and terrorism in the MENAP (Middle East, North Africa, Afghanistan, and Pakistan) region. Socio-Economic Planning Sciences, 64, 920.

Baloch, M. A., Khan, S. U. D., \&Ulucak, Z. Ş. (2020). Poverty and vulnerability of environmental degradation in Sub-Saharan African countries: what causes what?. Structural Change and Economic Dynamics.

Baltagi, B. H., Feng, Q., \&Kao, C. (2012). A Lagrange Multiplier test for cross-sectional dependence in a fixed effects panel data model. Journal of Econometrics, 170(1), 164-177.

Barbier, E. B. (2010). Poverty, development, and environment. Environment and Development Economics, 635-66o.

Bhattacharyya, S., \&Hodler, R. (2014). Do natural resource revenues hinder financial development? The role of political institutions. World Development, 57, 101-113.

Bist, J. P. (2018). Financial development and economic growth: Evidence from a panel of 16 African and non- African low-income countries. Cogent Economics \& Finance, 6(1), 1449780.

Brauner-Otto, S. R., \&Axinn, W. G. (2017). Natural resource collection and desired family size: a longitudinal test of environment-population theories. Population and environment, 38(4), 381-406. 


\section{Review of Economics and Development Studies, Vol. 7 (2) 2021, 131-145}

Breusch, T. S., \&Pagan, A. R. (1980). The Lagrange multiplier test and its applications to model specification in econometrics. The review of economic studies, 47(1), 239-253.

Cave, J., Chaudhuri, K., \& Kumbhakar, S. C. (2019). Do banking sector and stock market development matter for economic growth? Empirical Economics, 1-23.

Chaigneau, T., Coulthard, S., Brown, K., Daw, T. M., \& Schulte-Herbrüggen, B. (2019). Incorporating basic needs to reconcile poverty and ecosystem services. Conservation Biology, 33(3), 655-664.

Chaudhry, I. S., Faheem, M., Farooq, F., \& Ali, S. (2021). Financial Development and Natural Resources Dynamics in Saudi Arabia: Visiting 'Resource Curse Hypothesis' by NARDL and Wavelet-Based Quantile-on- Quantile Approach. Review of Economics and Development Studies, 7(1), 101-117.

Chidiebere, O. N., Iloanya, K., \&Udunze, U. (2014). Youth unemployment and entrepreneurship development: Challenges and prospects in Nigeria. Kuwait Chapter of the Arabian Journal of Business and Management Review, 4(4), 20.

Chudik A, Pesaran MH (2013) Large panel data models with crosssectional dependence: a survey. SSRN Electron J. https://doi.org/10.2139/ssrn.2316333.

Chudik, A., \&Pesaran, M. H. (2015). Common correlated effects estimation of heterogeneous dynamic panel data models with weakly exogenous regressors. Journal of Econometrics, 188(2), 393-420.

Corden, W. M., \& Neary, J. P. (1982). Booming sector and de-industrialisation in a small open economy. The economic journal, 92(368), 825-848.

Ding, Y., \& Peng, J. (2018). Impacts of urbanization of mountainous areas on resources and environment: $\quad$ Based on ecological footprint model. Sustainability, 10(3), 765 .

Ditzen, J. (2016). xtdcce: Estimating dynamic common correlated effects in Stata. The Spatial Economics and Econometrics Centre (SEEC).

Ditzen, J. (2019). Estimating long run effects in models with cross-sectional dependence using xtdcce2. Centre for Energy Economics Research and Policy (CEERP) Working Paper No, 7.

Dong, K., Hochman, G., Zhang, Y., Sun, R., Li, H., \& Liao, H. (2018b). CO2 emissions, economic and population growth, and renewable energy: Empirical evidence across regions. Energy Economics, 75, 180-192.

Dwumfour, R. A., \&Ntow-Gyamfi, M. (2018). Natural resources, financial development and institutional quality in Africa: Is there a resource curse?. Resources Policy, 59, 411-426.

Erum, N., \& Hussain, S. (2019). Corruption, natural resources and economic growth: Evidence from OIC countries. Resources Policy, 63, 101429.

Faisal, F., Sulaiman, Y., \&Tursoy, T. (2019). Does an asymmetric nexus exist between financial deepening and natural resources for emerging economy? Evidence from multiple break cointegration test. Resources Policy, 64, 101512.

Faisal, F., Sulaiman, Y., \& Tursoy, T. (2019). Does an asymmetric nexus exist between financial deepening and natural resources for emerging economy? Evidence from multiple break cointegration test. Resources Policy, 64, 101512.

Freeman, D., Inklaar, R., \&Diewert, W. E. (2020). Natural resources and missing inputs in international productivity comparisons. Review of Income and Wealth.

Fum, R. M., \&Hodler, R. (2010). Natural resources and income inequality: The role of ethnic divisions. Economics Letters, 107(3), 360-363.

Gelb, A., 2010. Economic Diversification in Resource Rich Countries. Center for Global Development, pp. 1-23.

Gill, I. S., Izvorski, I., Van Eeghen, W., \& De Rosa, D. (2014). Diversified development: making the most of natural resources in Eurasia. The World Bank. 


\section{Review of Economics and Development Studies, Vol. 7 (2) 2021, 131-145}

Girma, S., \& Shortland, A. (2008). The political economy of financial development. Oxford economic papers, 6o(4), 567-596.

Gokmenoglu, K. K., \& Rustamov, B. (2019). Examining the World Bank Group lending and natural resource abundance induced financial development in KART countries. Resources Policy, 63, 101433.

Grassa, R., \&Gazdar, K. (2014). Financial development and economic growth in GCC countries. International Journal of Social Economics.

Guan, J., Kirikkaleli, D., Bibi, A., \& Zhang, W. (2020). Natural resources rents nexus with financial development in the presence of globalization: is the "resource curse" exist or myth?. Resources Policy, 66, 101641.

Guan, J., Kirikkaleli, D., Bibi, A., \& Zhang, W. (2020). Natural resources rents nexus with financial development in the presence of globalization: is the "resource curse" exist or myth?. Resources Policy, 66, 101641.

Harding, T., \& Venables, A. J. (2016). The implications of natural resource exports for nonresource trade. IMF Economic Review, 64(2), 268-302.

Hassan, S. T., Xia, E., Khan, N. H., \& Shah, S. M. A. (2019). Economic growth, natural resources, and ecological footprints: evidence from Pakistan. Environmental

Science and Pollution Research, 26(3), 2929- 2938.

Hattendorff, C. (2014). Natural resources, export concentration and financial development (No. 2014/34). Diskussionsbeiträge.

Henri, P. A. O. (2019). Natural resources curse: A reality in Africa. Resources Policy, 63, 101406.

Huang, Y. (2010). Political institutions and financial development: an empirical study. World Development, 38(12), 1667-1677.

Ibrahim, M. H. (2019). Oil and macro-financial linkages: Evidence from the GCC countries. The Quarterly Review of Economics and Finance, 72, 1-13.

Ibrahim, M. H. (2019). Oil and macro-financial linkages: Evidence from the GCC countries. The Quarterly Review of Economics and Finance, 72, 1-13.

Im, K. S., Pesaran, M. H., \& Shin, Y. (2003). Testing for unit roots in heterogeneous panels. Journal of econometrics, 115 (1), 53-74.

Kapetanios, G., Pesaran, M. H., \& Yamagata, T. (2011). Panels with non-stationary multifactor error structures. Journal of Econometrics, 160 (2), 326-348.

Kayode, A., Arome, A., \& Silas, A. (2014). The rising rate of unemployment in Nigeria: the socioeconomic and political implications. Global Business and Economics Research Journal, 3(1).

Khan, A., Ahmed, M., \& Bibi, S. (2019). Financial development and economic growth nexus for Pakistan: a revisit using maximum entropy bootstrap approach. Empirical Economics, 57(4), 1157-1169.

Khan, H., Khan, S., \&Zuojun, F. (2020). Institutional Quality and Financial Development: Evidence from Developing and Emerging Economies. Global Business Review, 0972150919892366.

Khan, H., Khan, S., \&Zuojun, F. (2020). Institutional Quality and Financial Development: Evidence from Developing and Emerging Economies. Global Business Review, o972150919892366.

Kim, D. H., \& Lin, S. C. (2017). Natural resources and economic development: new panel evidence. Environmental and resource economics, 66(2), 363-391.

Kottutt, S. K., Sumukwo, J. Y., \& Omondi, P. (2020). Forest Ecosystem Resources for Alleviating Household Poverty in Eastern Mau, Kenya. Africa Environmental Review Journal, 3(2), 119.

Law, S. H., Tan, H. B., \& Azman-Saini, W. N. W. (2014). Financial development and income inequality at different levels of institutional quality. Emerging Markets Finance and 


\section{Review of Economics and Development Studies, Vol. 7 (2) 2021, 131-145}

Trade, 50(sup1), 21-33.

Law, S. H., Tan, H. B., \& Azman-Saini, W. N. W. (2015). Globalisation, institutional reforms and financial development in East Asian economies. The World Economy, 38(2), 379-398.

Levin, A., Lin, C. F., \& Chu, C. S. J. (2002). Unit root tests in panel data: asymptotic and finitesample properties. Journal of econometrics, 108 (1), 1-24.

Marchand, J., \& Weber, J. (2018). Local labor markets and natural resources: A synthesis of the literature. Journal of Economic Surveys, 32(2), 469-490.

Masron, T. A., \& Subramaniam, Y. (2019). Does poverty cause environmental degradation? Evidence from developing countries. Journal of poverty, 23(1), 44-64.

Mlachila, M., \&Ouedraogo, R. (2019). Financial development curse in resource-rich countries: The role of commodity price shocks. The Quarterly Review of Economics and Finance.

Muhammad, N., Islam, A. R. M., \& Marashdeh, H. A. (2016). Financial development and economic growth: an empirical evidence from the GCC countries using static and dynamic panel data. Journal of Economics and Finance, 40(4), 773-791.

Mukoka, S. (2020). DOES INFLATION INFLUENCE UNEMPLOYMENT IN ZIMBABWE? AN ECONOMETRIC ASSESSMENT. International Journal of Information, Business and Management, 12(2), 156-165.

Nawaz, K., Lahiani, A., \&Roubaud, D. (2019). Natural resources as blessings and finance-growth nexus: A bootstrap ARDL approach in an emerging economy. Resources Policy, 6o, 277-287.

Nwani, C. (2016). Finance and growth in oil-dependent economies: does crude oil price matter? evidence from Nigeria. OPEC Energy Review, 40(4), 354-373.

Nwani, C. (2016). Finance and growth in oil-dependent economies: does crude oil price matter? evidence from Nigeria. OPEC Energy Review, 40(4), 354-373.

Ouoba, Y. (2016). Natural resources: Funds and economic performance of resource-rich countries. Resources Policy, 50, 108-116.

Panayotou, T. (2016). Economic growth and the environment. The environment in anthropology, $140-148$.

Pedroni, P. (1999). Critical values for cointegration tests in heterogeneous panels with multiple regressors. Oxford Bulletin of Economics and statistics, 61(S1), 653-670.

Persyn, D., \&Westerlund, J. (2008). Error-correction-based cointegration tests for panel data. The STATA journal, 8(2), 232-241.

Pesaran, H., Smith, R., \&Im, K. S. (1996). Dynamic linear models for heterogenous panels. In the econometrics of panel data. Springer, Dordrecht, 145-195.

Pesaran, M. H. (2004). General diagnostic tests for cross section dependence in panels. CESifo Working Papers No.1233, 255-6o.

Pesaran, M. H. (2007). A simple panel unit root test in the presence of cross-section dependence. Journal of applied econometrics, 22(2), 265-312.

Pesaran, M. H., \& Smith, R. (1995). Estimating long-run relationships from dynamic heterogeneous panels. Journal of econometrics, 68(1), 79-113.

Pradhan, R. P., Arvin, M. B., Hall, J. H., \& Nair, M. (2016). Innovation, financial development and economic growth in Eurozone countries. Applied Economics Letters, 23(16), 1141-1144.

Rajan, R. G., \&Zingales, L. (2003). The great reversals: the politics of financial development in the twentieth century. Journal of financial economics, 69(1), 5-50.

Ricardo, D., 1911. Principles of Political Economy first published 1817. London, Dent.

Sachs, J. D., \& Warner, A. M. (2001). The curse of natural resources. European economic review, 45(4-6), 827-838.

Satti, S. L., Farooq, A., Loganathan, N., \& Shahbaz, M. (2014). Empirical evidence on the resource curse hypothesis in oil abundant economy. Economic Modelling, 42, 421-429. 
Review of Economics and Development Studies, Vol. 7 (2) 2021, 131-145

Satti, S. L., Farooq, A., Loganathan, N., \& Shahbaz, M. (2014). Empirical evidence on the resource curse hypothesis in oil abundant economy. Economic Modelling, 42, 421-429.

Shahbaz, M., Hye, Q. M. A., Tiwari, A. K., \&Leitão, N. C. (2013). Economic growth, energy consumption, financial development, international trade and $\mathrm{CO} 2$ emissions in Indonesia. Renewable and Sustainable Energy Reviews, 25, 109-121.

Simon, J. L. (2010). 59 More People, Greater Wealth, More Resources, Healthier Environment. Environmental Ethics: The Big Questions, 22(5), 447.

Sjöberg, O., Palme, J., \& Carroll, E. (2010). Unemployment insurance. In The Oxford handbook of the welfare state.

Smith, A., 1776. An Inquiry into the Wealth of Nations. Strahan and Cadell, London, pp. 1-11.

Suliman, A. H., \& Elian, M. I. (2014). Foreign direct investment, financial development, and economic growth: a cointegration model. The Journal of developing areas, 219-243.

Sun, Y., Ak, A., Serener, B., \&Xiong, D. (2020). Natural resource abundance and financial development: A case study of emerging seven (E-7) economies. Resources Policy, 67, 101660.

Timilsina, G. R., \& Zilberman, D. (2016). Impacts of Biofuels on the Economy, Environment, and Poverty. Springer-Verlag New York.

Tran, T. N., Nguyen, T. T., Nguyen, V. C., \& Vu, T. T. H. (2020). Energy Consumption, Economic Growth and Trade Balance in East Asia: A Panel Data Approach.

Vallejo, M. C. (2010). Biophysical structure of the Ecuadorian economy, foreign trade, and policy implications. Ecological Economics, 70(2), 159-169.

Westerlund, J. (2007). Testing for error correction in panel data. Oxford Bulletin of Economics and statistics, 69(6), 709-748.

Yıldırım, S., Gedikli, A., Erdoğan, S., \& Yıldırım, D. Ç. (2020). Natural resources rents-financial development nexus: Evidence from sixteen developing countries. Resources Policy, 68, 101705 .

Yıldırım, S., Gedikli, A., Erdoğan, S., \&Yıldırım, D. Ç. (2020). Natural resources rents-financial development nexus: Evidence from sixteen developing countries. Resources Policy, 68, 101705 .

Yuxiang, K., \& Chen, Z. (2011). Resource abundance and financial development: Evidence from China. Resources Policy, 36(1), 72-79.

Zaidi, S. A. H., Wei, Z., Gedikli, A., Zafar, M. W., Hou, F., \&Iftikhar, Y. (2019). The impact of globalization, natural resources abundance, and human capital on financial development: Evidence from thirty-one OECD countries. Resources Policy, 64, 101476.

Zhu, Q., Wu, J., Li, X., \&Xiong, B. (2017). China's regional natural resource allocation and utilization: a DEA-based approach in a big data environment. Journal of Cleaner Production, 142, 809-818.

Zoega, G., Gylfason, T., 2001. Natural Resources and Economic Growth: the Role Of Investment (No. 2743). CEPR Discussion Paper. 
Appendix

Table A1: Variable Description and Data Sources

\begin{tabular}{|c|c|c|c|}
\hline Variables & Description & Measurement (Unit) & Source \\
\hline LFD & $\begin{array}{c}\text { Log of financial } \\
\text { development }\end{array}$ & Broad Money to GDP & WDI \\
\hline LNRR & $\begin{array}{c}\text { log of natural resource } \\
\text { rent }\end{array}$ & $\begin{array}{c}\text { Total natural resource rent } \\
\text { (\% of GDP) }\end{array}$ & WDI \\
\hline LGDP & log of GDP & constant 2015 US\$ & WDI \\
\hline LINSQ & $\begin{array}{c}\text { Log of institutional } \\
\text { Quality }\end{array}$ & $\begin{array}{c}\text { Calculated through panel } \\
\text { principal component analysis } \\
\text { (PCA) }\end{array}$ & $\begin{array}{c}\text { International } \\
\text { Country Risk Guide } \\
\text { (ICRG) }\end{array}$ \\
\hline
\end{tabular}

